\title{
DOI 10.26886/2520-7474.4(36)2019.7
}

\section{UDC 74.01/.09 (569.5)}

\section{GLOBALIZATION AS A FORM OF CULTURAL INTERACTION IN CONTEMPORARY DESIGN DEVELOPMENT}

\section{Al Rawashdekh S.}

Lviv Polytechnic National University, Ukraine, Lviv

The article is devoted to the problem of traditional cultures functioning during the period of universal globalization and unification in the era of the information revolution. The purpose of the article is to identify the possibilities of design as an instrument for the preservation and development of culture. The task is to identify the factors that ensure the interconnection of the philosophical, scientific, technical, aesthetic and environmental spheres of global culture on the one hand, and productive interchange of achievements of regional and national cultures on the other hand. It is revealed that today, along with the globalization tendencies and unification in many spheres of human activity, for each people its genetic code, embedded in its own material culture, is best able to perform such important functions as harmonization of the environment, streamlining and orientation in information.

Key words: traditional culture, design, globalization, identity, local design.

Introduction. The concept of globalization covers society processes that reduce the dependence of social and cultural development on the geographical factor. This is the interaction of states, peoples, ethnic groups, social groups in a single system of open cultural exchange, expanding borders in all spheres of human activity, creating a global economic, ecological, informational and cultural space. Design is a practice that is 
involved in all spheres of this space. Throughout history, one can observe the desire to expand the influence of various cultures or values. The term "globalization" has spread from the 1980s in the works of the american sociologist R. Robertson, who began to systematically study the phenomenon, interpreting it as "compression of the world and intensive awareness of it as a whole" [1]. In the 1990's, synchronously with the significant economic growth of the Western world, the idea of globalization has become widespread, and the beginning of the third millennium demonstrates new mechanisms and information resources for its proliferation in post-industrial civilization.

Analysis of recent research and publications. Among the studies devoted to the question of globalization in the practice of design researches of V. Danylenko, D. Grossman, J. C. Diehl, C. M. Christiaans, O. Snegovaya $[2 ; 3 ; 4 ; 5]$. However, the issue of globalization as a cultural interconnection is still uncovered. The disclosure of the impact of globalization on the interaction of local cultures requires a more thorough study.

Objectives. The purpose of the article is to identify the possibilities of design as an instrument for the preservation and development of culture in the context of globalization processes.

Presentation of the main material of the article. The dictionary of foreign words defines the notion of "globalization" - as the transformation of a certain phenomenon into a phenomenon that has a global, planetary significance and applies to the entire planet Earth. Despite the fact that globalization processes can be used in different periods of human development, it is at the end of the twentieth century a system based on global interaction is being formed. Culture is an essential area of this system, and the key trends that influence the process are the intensification of cultural interactions in the information society; strengthening of the 
integrative tendencies in culture; domination of Western culture; changes in the values and normative principles of national cultures in the process of modernization of society; globalization of symbols and universals in mass culture; expansion of the functioning and influence of individual languages (as in English) in media and cultural space [5].

At the time of the creation of a trans-local culture that spreads ignoring national boundaries, only the actualization of local traditions can ensure the existence of cultural diversity. The support and development of these traditions will preserve the unique image of individual cultures and strengthen the overall global cultural background. At the same time, today it is impossible to live exclusively at the expense of our own cultural heritage and the result is the coexistence of modern local in the modern global, that is, the ratio of local cultural traditions to the general problems of the development of culture as a whole. An important factor in the interaction of global and local is the "ethnic paradox" of modernity, that is, the enhancement of ethnic consciousness with the weakening of the ethnic characteristics of traditional culture [6].

Preservation of cultural identity in the general background of acculturation and assimilation is now regarded as a higher achievement of civilization. Globalization promotes the formation of an understanding of the interconnected world, cultural pluralism, increases the density of the "information flow", gives the chance to different cultures to escape beyond the limits of their seclusion, to get a push for further development. Globalization contributes to the growth of the pace of the creation, distribution and consumption of cultural property. The cycle time for the creation and consumption of cultural property is reduced, thus increasing the amount of information that needs to be taken. Consequently, on the one hand, people in particular and the ethnos as a whole should be "socially mobile" than in previous eras and more intellectual, creative. On the other 
hand, the problem of national heritage, the necessity and the possibility to preserve all the uniqueness of the culture of the ethnic group comes to the fore.

Each country, nation, and ethnic group feel and react to cultural globalization processes in different ways. Jordan belongs to the Muslim countries, therefore, there are a number of factors that significantly influence the cultural interactions and interactions of this Middle Eastern country. It can be argued that some of the neighboring countries of Jordan, in particular, Iran, are actively opposed to the policies of global globalism, against the usurpation of their own national priorities by any outside system of values. At the same time, such states are forced to take into account the fact that it is impossible to fully control the process of consumption of cultural products of the western industry of art, entertainment, cinema, etc., with its orientation towards the corresponding visual and content values. There is an understanding that measures of a prohibitive or insular nature will not produce the desired result. Therefore, the principle of functioning of cultures in modern conditions should be interaction, and its basic principle is dialogue based on partnership and recognition of the equality of cultures. Representatives of the most conservative traditional cultures recognize that the assimilation of new forms is a moment of self-development, so it is impossible to avoid contacts and borrowings. Along with this, the question arises about preserving and protecting the originality of traditional cultures, their creative development. Iranian philosopher Nasr S. Kh. Believes that the modern era "... in connection with the processes of globalization revealed the problem of civilizational identity. Certain societies, such as China, India, Islamic, faced the threat of the disappearance or transformation into peripheral cultures of world civilization, built on the principle of Western civilization. Hence - the desire of these societies to defend their identity " [7, p. 37]. 
The design is particularly evident in globalization trends. As a "new thinking" of civilized post-industrial society, design is in itself a global phenomenon, but encompasses the most diverse areas of human life, forming a substantive, informational and communicative world and the environment. Industrial revolution at the turn of the nineteenth and twentieth centuries. led to the mass production of goods and led to the loss of control and new ideas about "beautiful". At the same time, individual production with its aesthetics and attitude to the environment went to the background, and the apogee of mass became the 1960's with their minimalism and commercialization of processes. Today, further development of mankind is impossible without the preservation of the environment and the development of new philosophical concepts. The design has a high potential in solving both social and cultural as well as environmental problems. F. Stark in the early 2000's stated: "A quarter century ago, the ultimate goal of designers was to create the design and appearance of a separate item. Today they must constantly propose new ecological and philosophical values, a vision of the evolution of civilization, and not simply a style and fashion trends» [8]. Modern design theories treat it differently: as a means of improving the quality of life through technical and aesthetic parameters; as an advertising aggressor and distributor of surface decoration; as a particular subculture, based on primitive simulation of fashionable forms and successful brands. But there is a common vision of the fact that in the XXI century. the design has entered a new stage of development and can be interpreted as the art of layout, stylistics and aesthetization of the object in the context of environmental problems. Ukrainian researcher $V$. Danilenko, giving definition of design, believes, in particular, that it is "... Westernized artistic and design activity on the basis of high technologies of Western origin" [2, p.25]. This view very precisely characterizes the essence of globalization processes precisely in design, 
as an extrapolation of the industrial revolution. Its consequence, the response to the introduction of new technologies and mass production, the growth of international trade and the consumption of the middle class has become due to almost two centuries global distribution of design, with its ability to fundamentally positive or negative impact on humanity [3]. At the same time, the researcher Danilenko believes that Westernization of artistic and technical culture of the whole world has a superficial character. The West, in his opinion, is not capable of invading the archetypes of other cultural and civilizational conglomerates so that they can radically change them, likening themselves, including in the field of design [2].

Thus, ethno-cultural differences are permanently manifested in design products with similar functional capabilities. The type and form of products affects the degree to which they possess the characteristics of cultural diversity. For example, in such subjects as electronic equipment or automotive industry, the work of the designer is present, at the same time, there are no differences associated with cultural diversity. The reason is obvious: the very nature of the production process of batch production does not allow for significant differences between product batches for different consumers around the world. More often than not, this applies to the vast majority of industrial production of mass production, because in some cases, ethno-cultural differences are seriously contrary to the principle of homogeneity of mass production. Globalization has led to a situation in which groups of products are developed in one culture for use in a completely different cultural environment. Globalization also gives companies and their designers a choice between "global" or "local" product design.

In general, the influence of the cultural factor on product design is shaped by the following factors: design education; practical design; cultural level of the designer; aesthetic needs of society; consumption of a 
particular product. Today, companies, both consumer and intellectual products, are implementing their business, given the importance of flexible and adaptive design in accordance with local markets. The company's inability to attract and adapt in its products the cultural diversity of a particular state or region often limits its commercial success. Therefore, today a number of global companies have already begun to develop methods for cross-cultural research. In particular, Intel has developed its own "cultural capsule", a physical cultural environment that can imitate any cultural interior or atmosphere. Microsoft, Hewlett Packard and Philips conduct cross-cultural research to understand the interaction of culture and humans in design; are looking for a way to effectively adapt product advertising to local preferences, ignoring global solutions [4].

One of the significant circumstances in the process of understanding cultural interactions in the context of design is the level of perception and understanding of borrowed cliché forms and their own artistic components. This circumstance is equally relevant in all areas of modern design, as it manifests itself in the synthesis of universal solutions and unique traditions of traditional cultures.

The embodiment of the national values of any culture in graphic or volumetric-spatial forms of creative activity is potentially connected with the synthesis of aesthetic expressiveness and practical benefit. After all, it is the national forms that are most effective in terms of their perception. They make it impossible to dissonance that may arise between foreign value characteristics and visual national archetypes.

Attempts to revive the lost diversity of the subject-spatial environment, degraded by the world of "international" design, are synchronized with the actualization of the process of revival of the most vivid examples of local national cultures that have become symbols of the existence of culture in particular periods. Design in search of cultural identity increasingly appeals 
to the theme of traditional art, regional cultural values, on the basis of which are implemented its cultural and environmental principles. To create ethnocultural designs, the design uses forms of folk art.

Conclusions and prospects for further research. In general, we can conclude that innovation is impossible without experience. Traditions allow a person to not get lost, and adapt his lifestyle to the rapid changes of the modern world. Globalization requires local cultures not to conquer and dissolve, but to selectively selectively perceive and master the new experience of other civilizations, which is possible only in the process of constructive dialogue. An important aspect of globalization is that it promotes the creation of a new type of identity - the "universal designercreator». This aspect, at the same time, does not require the complete destruction of centuries-old system of values of a certain ethnic group through the unification or substitution of other forms, up to the loss of identity. Along with the globalization tendencies and unification in many spheres of human activity, the genetic code of each nation, laid in its material culture is best is capable of performing such important design functions as:

1. Organization and orientation in the information environment by using the best achievements of a global society.

2. Harmonization of the environment by synthesizing local and global values.

Consequently, the foreground is the formation of new senses, values and norms that take into account the needs of the human and local. And design is formed as a means of harmonizing the environment, designing human experience, designing a social context with global significance. The balance of borrowed universal forms and national artistic components of traditional cultures is important.National forms are most effective for a particular people in terms of their perception. 


\section{References:}

1. Robertson R. (1992) Globalization: Social Theory and Global Culture. London: Sage [in English].

2. Danylenko, V. (2005). Dyzain Ukrainy u svitovomu konteksti khudozhnoproektnoi kultury [Design of Ukraine in the World Context of Art and Design Culture]. Kharkiv: KhDADM, Koloryt. [in Ukrainian].

3. Grossman, D. (2017). Globalisation and Design: Midterm Reflections. ico-d <https://www.ico-d.org/2017/01/10/globalisation-and-design-mid-termreflections.php [in English]. (2019, Jule, 25).

4. Diehl, J.C., Christiaans, H.H.C.M. (2006). Globalization and cross cultural product design. International design conference - design 2006. Dubrovnik - Croatia (May 15 - 18, 2006). <https://www.designsociety.org/publication/19040/GLOBALIZATION+AND+ CROSS-ULTURAL+PRODUCT+DESIGN [in English]. (2019, Jule, 28).

5. Snegovaja, O. Dolganovskaja, N.(2015). Aspekty kul'turnoj dinamiki v teorijah globalizacii [Aspects of cultural dynamics in the theories of globalization] Izvestija vysshih uchebnyh zavedenij. Severo-Kavkazskij region. Obshhestvennye nauki [News of higher educational institutions. North Caucasus region. Social sciences]. no 4. Retrieved from https://cyberleninka.ru/article/n/aspekty-kulturnoy-dinamiki-v-teoriyahglobalizatsii [in Russian]. (2019, Jule, 28).

6. Shkaratan, O. (1986). Jetnosocial'nye problemy goroda [Ethno-social problems of the city]. Moskva: Nauka. [in Russian]. (2019, Jule, 20).

7. Nasr S.H. (2009). Islamskoe iskusstvo $i$ duhovnost [Islamic art and spirituality]. Moskva: «Dizajn. Informacija. Kartografija». [in Russian]. (2019, Jule, 20).

8. Sheppard, S. (2012). 10 Insights into the Design Mind of Philippe Starck. $<$ https://freshome.com/2012/10/18/10-insights-into-the-design-mind-ofphilippe-starck/ [in English]. (2019, June, 10). 
